Дакал Алла Василівна доктор наук 3 державного управління, доцент кафедри публічного адміністрування Навчально-наукового інституту міжнародних відносин та соціальних наук ПрАТ "Вищий навчальний заклад "Міжрегіональна Академія управління персоналом", 03039 Київ, вул. Фрометівська, 2, тел.+380678904646, email: a_dakal@nuozu.edu.ua, https//orcid.org/0000-0003-3221-353X

\title{
ДЕРЖАВНА ПОЛІТИКА ЗАХИСТУ ПРАВ ДІТЕЙ ЯК ФОРМА РОЗВИТКУ ГРОМАДЯНСЬКОГО СУСПІЛЬСТВА
}

Анотація. Стаття присвячена розгляду сучасних наукових підходів до взаємодії органів влади та громадських організацій щодо формування та реалізації державної політики щодо захисту прав дітей. Розкрито роль інституцій громадянського суспільства у формуванні та реалізації такої політики. Охарактеризовано напрямки взаємодії інституцій громадянського суспільства та органів державної влади й місцевого самоврядування щодо забезпечення конституційних гарантій прав дітей.

Обгрунтовано, що державна політика в цілому, та державна соціальна політика захисту дітей являє собою певну як форму розвитку громадянського суспільства, обумовлену зростанням його ролі та значення у процесах демократичного суспільного розвитку. Відтак захист прав дитини потребує системної державної політики, що обумовлено наявністю однієї з найважливіших політичних функцій держави з регулювання внутрішнього життя суспільства де серед пріоритетних напрямів соціального блоку діяльності органів публічного врядування є охорона дитинства, материнства, батьківства тощо.

Зроблено висновок щодо необхідності забезпечення невід'ємних прав та законних інтересів дітей як стратегічного чинника демократичного державотворення. При цьому зміст заходів державної політики щодо захисту прав дітей не можна відривати від інституційного середовища, територіальних громадян та їх організацій і об'єднань, з урахуванням специфіки історичного розвитку, типу соціальної організації та сучасних суспільно-політичних реалій. На підставі узагальнення експертно-фахового бачення напрямів подальшої розбудови та вдосконалення системи забезпечення та захисту прав дітей в Україні запропоновано низку заходів формування дієвої державної політики підтримки та стимулювання материнства й дитинства, заснованої на загальновизнаних європейських стандартах.

Ключові слова: держава, державна політика, права дитини, захист прав та інтересів дітей, громадянське суспільство, європейські стандарти захисту дитини. 
Dakal Alla Vasylivna D.Sc. of Public Administration, Associate Professor Department of Public Administration Educational-Scientific Institute of International Relations and Social Sciences Private higher education institution "Interregional Academy of Personnel Management", 03039 Kyiv, street Frometivska, 2, tel.+380678904646, email: a_dakal@ nuozu.edu.ua, https//orcid.org/0000-0003-3221-353X

\section{STATE POLICY FOR THE PROTECTION OF CHILDREN'S RIGHTS AS A FORM OF CIVIL SOCIETY DEVELOPMENT}

Abstract. The article is devoted to the consideration of modern scientific approaches to the interaction of authorities and public organizations on the formation and implementation of state policy on the protection of children's rights. The role of civil society institutions in the formation and implementation of such a policy is revealed. The directions of interaction between the institutions of civil society and bodies of state power and local self-government on providing constitutional guarantees of children's rights are described.

It is substantiated that the state policy in general and the state social policy of child protection is a certain form of civil society development, due to the growth of its role and importance in the processes of democratic social development. Therefore, the protection of children's rights requires a systematic state policy, due to the presence of one of the most important political functions of the state to regulate the internal life of society where among the priorities of the social block of public administration is the protection of childhood, motherhood, fatherhood and more.

The conclusion is made about the need to ensure the inalienable rights and legitimate interests of children as a strategic factor in democratic statehood. At the same time, the content of state policy measures to protect children's rights cannot be separated from the institutional environment, territorial citizens and their organizations and associations, considering the specifics of historical development, type of social organization and modern socio-political realities.

Based on the generalization of expert-professional vision of further development and improvement of the system of ensuring and protecting children's rights in Ukraine, several measures to form an effective state policy to support and stimulate motherhood and childhood, based on generally accepted European standards.

Keywords: state, state policy, children's rights, protection of children's rights and interests, civil society, European standards of child protection.

Постановка проблеми. Сучасна Україна знаходиться у стані гострої демографічної кризи, популяція українців щороку скорочується пришвидшеними темпами, кількість дітей в країні з 1991 по 2020 рр. скоротилася практично вдвічі, молоді сім'ї все більше утримуються від народження дитини та виїжджають на заробітки до інших країн. За таких умов функція соцієтального й біологічного відтворення суспільства вже не може залишатися переважно завданням органів публічного врядування й має все більше охоплювати 
структури громадянського суспільства. Ми маємо розглядати дитину "як основу формування і розвитку потужного пласта людського капіталу в майбутньому, та робить висновок, що сьогодні на часі назріли докорінні зміни в підходах до формування та розвитку людського капіталу в Україні та світі, основою яких має стати концепція забезпечення безпеки дитини, реалізації їі інтересів" [12, с. 166].

Таким чином, 3 точки зору самого виживання української держави та українського народу гостро постає проблема збільшення пропорційності кількості дітей і молоді в демографічній структурі нашого суспільства. У свою чергу, це актуалізує широку участь інституцій громадянського суспільства в процесах досягнення європейських стандартів захисту прав і законних інтересів дітей в Україні, створення на цих стандартах дієвої національної системи захисту дитинства, розробки та упровадження публічної політики стимулювання народження та виховання дітей в Україні як стратегічної складової подальшого державотворення. Розкриття та теоретичне осмислення даної проблеми дозволить вирішити важливе науково-прикладне завдання подолання демографічної кризи, зменшення відтоку молоді за кордон, закладання підвалин для зростання української людності що $\epsilon$ особливо актуальним для демократизації державотворчих процесів в Україні та самого їх існування.

Аналіз останніх досліджень і публікацій свідчить, що проблематиці захисту прав і законних інтересів дітей, участі в цих процесах інституцій громадянського суспільства в сучасному українському дискурсному полі приділено значну увагу. Зокрема, проблематиці розкриття європейських стандартів прав дитини присвячено роботи таких дослідників та експертів як О. Антонова [1], О. Дрозд і Т. Хуторянська [2], О. Користін та М. Веселов [3], Н. Крестовська [4], О. Кудрявцева [5], Ю. Олефіренко [6], О. Проць та Р. Романків [7], О. Радченко та С. Погорелий [8], Т. Серьогіна [10], О. Тильчик та О. Мердова [11], Ю. Трестер [12]. Проте, незважаючи на в цілому грунтовну розробленість зазначеної проблематики, вітчизняними вченими розглядалися окремі, переважно іiі інституціональні аспекти, а дослідженню проблеми впливу громадськості на формування та реалізацію державної політики щодо захисту прав дітей приділялося недостатньо уваги.

Саме цим обумовлена постановка мети і завдань даної статті як проведення огляду й систематизації практика взаємодії органів влади та громадських організацій щодо захисту прав i законних інтересів дітей, політичних технологій взаємодії громадян з органами влади у сфері формування та реалізації державної політики щодо захисту прав дітей.

Виклад основного матеріалу дослідження. Проблематика захисту прав дитини давно вийшла за межі домінування держави, державної політики та відповідних органів публічного врядування. Сьогодні це $\epsilon$ одним 3 основоположних напрямків діяльності численної кількості місцевих, національних та міжнародних громадських i суспільно-політичних та міждержавних i наддержавних організацій, як Свропейського Союзу та Організації Об'єднаних Націй. Піклування про дітей в сучасному світі все більше означає піклування про майбутні покоління - про саме продовження існування людської цивілізації. Протягом останніх 50-ти років світове громадянське 
суспільство та міжнародна спільнота виробили й ухвалили значну кількість договорів, що стосуються захисту прав i законних інтересів дітей, що дає підстави стверджувати про певну усталеність міжнародної системи стандартів в цій сфері.

Зокрема, ключовим документом у сфері захисту дитини, своєрідною "міжнародною дитячою конституцією" $\epsilon$ Конвенція про права дитини, яка прийнята Генеральною Асамблеєю ООН 20 листопада 1989 року (станом на початок 2020 р. вона $є$ ратифікованою всіма державами світу, окрім США, Південного Судану та Сомалі). Як зазначає О. Антонова, саме з цієї Конвенції розпочалося формування системи міжнародних стандартів щодо захисту прав дітей [1, с. 106]. Конвенція закріпила гуманітарний дитиноцентричний підхід політико-правових заходів щодо забезпечення людської гідності дитини, і1і моральних та правових аспектах. При цьому людська гідність дитини виступає первісним витоком усіх прав людини і розуміється як прийняття та належність кожної дитини до людського роду за простим фактом народження як рівної, достойної перебування у статусі людини і такої, що володіє правами та моральними імперативами людини [4, с. 37].

У рамках Конвенції про права дитини держави-учасниці ООН зобов’язалися забезпечити неповнолітній особі такий захист і піклування, які необхідні для їі благополуччя, беручи до уваги права й обов'язки батьків чи інших осіб, які відповідають за дитину за законом, й із цією метою вживають усіх відповідних законодавчих i адміністративних заходів. При цьому особлива увага покладається на обов'язок національних публічних адміністрацій вживати комплекс заходів щодо забезпечення найкращих інтересів дитини як основного предмету піклування держави. Крім того, мають вживатися необхідні законодавчі, адміністративні, соціальні заходи 3 метою захисту дитини від усіх форм фізичного та психологічного насильства, образи чи зловживань, відсутності піклування, жорстокого поводження, експлуатації з боку батьків чи іншої особи, яка за законом турбується про дитину [2, с. 259].

Від самого початку з метою більш плідної реалізації положень Конвенції про права дитини до цієї діяльності включилися організації громадянського суспільства. Зокрема, у червні 1997 р. було створено міжнародне неприбуткове об'єднання незалежних інститутів 3 прав дітей - Свропейську мережу уповноважених 3 прав дітей (ENOC). Сьогодні іiі членами є 27 країн, більшість 3 яких є членами Свросоюзу. Як свідчить практика, саме інститут уповноважених 3 прав дітей - дитячих омбудсменів - став найбільш поширеним i найбільш впливовим механізмом захисту прав і законних інтересів дитини в Свропі.

Роль інституцій громадянського суспільства у формуванні та реалізації публічної політики захисту прав та законних інтересів дітей визначається їх впливом на діяльність органів державної влади та місцевого самоврядування щодо забезпечення конституційних гарантій прав дітей за такими напрямами:

- формування суспільного запиту та суспільне лобіювання необхідних змін нормативно-законодавчої бази щодо внесення обгрунтованих коректив для закріплення відповідальності різних виконавчих структур органів публічного врядування за дотримання чинного законодавства; 
- активна участь у процесах соціалізації дітей та молоді, спрямована на всебічне розкриття, самореалізацію творчого соціального потенціалу дітей, задоволення ними соціальних потреб та інтересів, освоєння соціальних цінностей;

- інституційна розбудова системи захисту прав дітей в державі, що визначає організаційне середовище та повноваження структур, які беруть участь у формуванні та реалізації публічної політики щодо захисту прав дітей;

- запровадження діалогової комунікації громадянського суспільства та органів публічного врядування як певної політичної технології [8], що дозволяє визначити узгоджені засоби для розробки та втілення в життя відповідних програм та заходів, створення умов для соціального поступу в зазначеній сфері життєдіяльності суспільства;

- вплив на суспільно-економічну діяльність, призначення якого полягає в покращенні умов праці матерів, забезпеченні необхідного для повноцінного розвитку дитини матеріального рівня доходів молодих сімей тощо;

- розвиток політичної культури суспільства, духовних, культурних, громадських цінностей, які створюють підвалини формування механізмів гармонізації суспільних відносин з метою забезпечення дотримання та захисту прав дітей;

- функціональна участь громадських об'єднань та організацій у волонтерській та благодійній діяльності, зокрема, у вигляді надання послуг у сфері захисту прав дітей як одного з різновидів соціальних послуг соціальної сфери країни в цілому [10, с. 69];

Зазначені вище напрямки свідчать, що у свою чергу, державна політика в цілому, та державна соціальна політика захисту дітей являє собою певну форму розвитку громадянського суспільства, обумовлену зростанням його ролі та значення у процесах демократичного суспільного розвитку. Роль інституцій громадянського суспільства в українських реаліях посилюється внаслідок того, що в нашій державі "попри задекларовані принципи та високий рівень фінансування сфери захисту прав дітей, система захисту прав дітей $\epsilon$ неефективною й шкідливою як для дітей, так і для суспільства" [10, с. 69]. Така ситуація пояснюється експертами тим, що дитина розглядається не як суб'єкт власних прав, а як об'єкт захисту. При цьому "багато норм законодавства щодо прав дитини залишаються декларативними, не всі права дитини, визначені Конвенцією ООН про права дитини знайшли відображення у національному законодавстві" [11, с. 114].

Очевидно, що захист прав дитини потребує системної державної політики. Це обумовлено наявністю однієї з найважливіших політичних функцій держави 3 регулювання внутрішнього життя суспільства де серед пріоритетних напрямів соціального блоку діяльності органів публічного врядування фахівці відносять, зокрема, й охорону дитинства, материнства, батьківства тощо. Відомо, що у соціальному плані діти становлять собою одну 3 найбільш вразливих верств населення, потребують усебічного захисту їхніх прав; про це мають дбати як державні, так і недержавні інституції, адже стабільний розвиток будь-якої держави в майбутньому визначається становищем дітей на даний час. 
Останнім часом увага громадськості прикута до загострення старих та виникнення нових системних загроз правам та інтересам дитини в світі та Україні. Зокрема, з глобальною популяризацією соціальних мереж та вільним доступом до них соціально незрілих школярів у поєднанні 3 посиленням кризових явищ в системі загальної середньої освіти, на передній план виступає проблема булінгу, від якого щодня потерпає все більше осіб. Як з жалем констатують О. Проць та Р. Романків, сьогодні Україна є одним зі світових лідерів за показниками булінгу - цькування серед дітей [7, с. 127]. Цю думку поділяють фахівці Університету державної фіскальної служби України О. Тильчик та О. Мердова, які стверджують, що "на сьогоднішній день вкрай важливим залишаються питання розбудови діяльності державних органів щодо протидії "новим" негативним явищам у дитячому середовищі, як приклад, протидія домашньому насильству, протидія боулінгу, протидія тенденції розповсюдження суїцидальних проявів серед дітей тощо. На нашу думку, до діяльності щодо протидії таким негативним проявам в дитячому середовищі повинні системно залучатися працівники правоохоронної системи, органів опіки та піклування, представники соціальної та педагогічної спільнот, співробітники медичної і психологічної служб" [11, с. 116].

Так само міжнародна та вітчизняна громадськість звертають особливу увагу на необхідності посилити заходи зі сприяння розвитку цифрової грамотності, в тому числі щодо формування критичного розуміння дітьми цифрового середовища й освітніх ресурсів. 3 огляду на швидкість виникнення нових технологій, керівні принципи Рада Європи пропонує національним державам запровадити термінові заходи щодо подолання ризиків для дітей у цифровому середовищі, зокрема такі, як: регулярні оцінки ризиків, використання ефективних систем перевірки віку, створення принципів для товарів/послуг, які адресовані дітям або використовуються ними. Обов'язковий захист дітей від комерційної експлуатації та, невідповідної їх вікові, рекламі та маркетингу. А також шкідливого контенту, сексуальної експлуатації, насильства, розбещення, онлайн-вербуванню для вчинення злочинів, участі в екстремістських політичних чи релігійних рухах, торгівлі людьми; від залякування, переслідування та інших форм насильства.

Згідно Рекомендацій Комітету міністрів СС державам-членам про принципи дотримання, захисту та реалізації прав дитини в цифровому середовищі держави повинні гарантувати права дитини на отримання та висловлення будь-яких поглядів, думок або висловлювань із важливих для них питань через засоби масової інформації за їх вибором та незалежно від того, чи їхні погляди й думки були позитивно сприйняті державою чи іншими учасниками. Для цього державам слід вживати відповідних заходів для того, щоб всі діти мали адекватний, доступний та надійний доступ до пристроїв, підключення, послуг i контенту, які спеціально призначені для дітей; у спеціальних публічних просторах такий доступ має бути безоплатним. Водночас, слід уживати спеціальних заходів для захисту малолітніх дітей від передчасного впливу цифрового середовища [9].

У контексті даного дослідження дня нас $є$ цікавим досвід такого нашого 
найближчого сусіда в Східній Європі як Польща. Унікальність польського досвіду полягає в тому, що ця країна єдина в світі закріпила в своїй Конституції низку конкретних гарантій прав дитини, зокрема вимога до органів публічної влади захищати дитину від насильства, жорстокості, експлуатації та деморалізації, враховувати зрілість дитини, а також свободу їі совісті й визнання iii переконання та необхідність в процесі встановлення прав дитини "вислухати і в міру можливості врахувати думку дитини (Статті 48 та 72 Конституції РП). Як зазначає О. Кудрявцева Польща демонструє такий системний комплексний підхід до унормування прав i свобод дитини через суттєвий вплив громадянського суспільства на Польську державу в питаннях захисту прав дитини. Конституційна новела про заснування посади дитячого омбудсмана стала результатом впливу громадського сектору, зокрема такої авторитетної громадської організації з 40-річною історією, як «Комітет охорони прав дитини». До того ж, не слід забувати і багаті правозахисні традиції в Польщі. Адже саме цінності та погляди відомого польського педагога Я. Корчака стали світоглядною основою Конвенції ООН про права людини [5, с. 60].

Цікавим є той факт, що польські дітлахи вперше дізнаються про свої права та існування Захисника прав дитини із підручників, зокрема 3 книги "Польща моя батьківщина", із листів омбудсмана до дітей, які зачитують керівники усіх шкіл на початку нового навчального року, а також із численних телевізійних $\mathrm{i}$ радіопередач, соціальних мереж тощо.

Звичайно, кожному суспільству, кожній конкретній країні притаманні свої особливості, а відтак - різняться підходи до формування та реалізації публічної політики щодо захисту прав дітей, які залежать від сутності суспільства, пануючих у ньому економічних відносин, політичних інститутів, історичного досвід, рівня взаємодії органів публічного врядування та інституцій громадянського суспільства. Тому зміст заходів державної політики щодо захисту прав дітей не можна відривати від інституційного середовища, територіальних громадян та їх організацій i об'єднань, а запозичення та впровадження досвіду інших країн має відбуватися виважено, на науковому підгрунті, 3 урахуванням специфіки історичного розвитку, типу соціальної організації та сучасних суспільно-політичних реалій.

3 урахуванням таких застережень 3 позицій науки державного управління пропонуємо узагальнення експертно-фахового бачення напрямів подальшої розбудови та вдосконалення системи забезпечення та захисту прав дітей в Україні, зокрема, таких як:

- створення чіткої вертикалі управління у сфері захисту сімей та дітей;

- удосконалення діяльності органів опіки та піклування сільського та міського рівня;

- роздержавлення сфери соціальних послуг, поступового переходу від великих інституційних форм надання соціальної допомоги до запровадження та розвитку на рівні громад малокомплектних центрів 3 денним або стаціонарним утриманням для надання комплексних послуг превентивного характеру, без відриву дитини від родини (Ю. Олифіренко [6, с. 274]); 
- розроблення та затвердження мінімальних стандартів благополуччя та безпеки дитини;

- розроблення та затвердження концепції підтримки та сприяння розвитку дитячого громадського руху в Україні;

- забезпечення дієвої координації державних органів, які представляють різні гілки влади й рівні управління, а також органів місцевого самоврядування щодо забезпечення та контролю за дотриманням прав дітей в Україні;

- обов'язкове запровадження технологій медіації у всіх закладах освіти;

- запровадження сталих моделей підготовки та перепідготовки спеціалізованих кадрів державних органів, що здійснюють реалізацію ювенальної політики, в частині застосування нових форм та методів їх діяльності;

- удосконалення механізмів діяльності державних органів щодо розвитку системи правової освіти дітей і їх батьків, підвищення рівня їх правосвідомості (О. Тильчик та О. Мердова [11, с. 117-118]);

- поширення ефективних технологій соціальної роботи, які передбачають опору на власну активність громадянського суспільства, громадян та власне дітей;

- надання державою дітям можливості брати участь у вирішенні своїх проблем разом з фахівцями урядових та неурядових інституцій;

- запровадження принципу субсидіарності у наданні допомоги 3 боку держави та громадськості з орієнтацією на розвиток внутрішніх ресурсів сім'ї, задоволення потреб дитини та реалізовані за підтримки держави;

- формування режиму збалансованого правового регулювання та впливу або втручання (через заходи соціального, економічного, правового, культурновиховного та організаційного характеру (державних органів та громадянського суспільства (місцевої громади) у ювенальні відносини з приводу створення або підтримання належних умов життєдіяльності та розвитку дитини, охорони та захисту її прав і свобод, своєчасної кореляції негативних факторів, що впливають на соціалізацію дитини з тим, щоб з віком вона могла повністю покласти на себе зобов'язання в межах суспільства як його повноцінний член (О. Користін та М. Веселов [3, с. 95]).

Висновки. Таким чином, проведене дослідження надає підстави для твердження, що проблема державного захисту прав і законних інтересів дітей в сучасному світі набуває стратегічного значення. А їі позитивне вирішення надає імпульс подальшому державотворенню та розвитку соціальних спільнот в усьому світі, закладаючи підвалини майбутньої конкурентоздатності цілих народів і держав. Встановлено, що державна політика в цілому, та державна соціальна політика захисту дітей являє собою певну як форму розвитку громадянського суспільства, обумовлену зростанням його ролі та значення у процесах демократичного суспільного розвитку. Відтак в Україні необхідно розширювати й активізувати діяльність структур громадянського суспільства, формувати нову більш послідовну й дієву державну політику підтримки та стимулювання материнства й дитинства, засновану на загальновизнаних європейських стандартах. 


\section{Перспективи подальших досліджень полягають у необхідності} проведення актуальних досліджень щодо вироблення пропозицій щодо більш глибокої взаємодії органів публічного врядування та інституцій громадянського суспільства у напрямку імплементації міжнародних стандартів захисту прав i законних інтересів дитини в Україні, упровадження кращого європейського досвіду у формуванні та реалізації державної соціальної й молодіжної політики в частині захисту материнства i дитинства, вироблення пропозицій щодо удосконалення державних механізмів захисту дітей, гарантування їх невід'ємних прав та законних інтересів як важливого стратегічного чинника демократичного державотворення в Україні.

\section{Лimepamypa:}

1. Антонова О. Міжнародно-правові стандарти у сфері сім’і, дитинства, материнства і батьківства. Альманах міжнародного права. 2017. Вип. 18. С. 103-112.

2. Дрозд О., Хуторянська Т. Міжнародні стандарти забезпечення прав і законних інтересів дитини та їх імплементація в законодавство України. Актуальні проблеми держави $i$ права. 2015. Вип. 75. С. 255-261.

3. Користін О. Є., Веселов М. Ю. Теоретико-методологічні засади щодо концептуалізації інституту забезпечення прав дітей. Наука і правоохорона. 2019. № 1. С. 91-99.

4. Крестовська Н. Людська гідність дитини: моральні та правові аспекти. Evropsky politicky a pravni diskurz. 2018. Vol. 5, Iss. 5. C. 35-41.

5. Кудрявцева О. Конституційні та інституційні засади захисту прав дитини в Україні та Польщі: порівняльно-правовий аналіз. Історико-правовий часопис. 2016. № 2. С. 58-62.

6. Олифіренко Ю. Шляхи вдосконалення державного управління у сфері захисту прав дитини. Вісник Чернігівського державного технологічного університету. Серія : Економічні науки. 2014. № 2. С. 264-275.

7. Проць О. С., Романків Р. В. Протидія булінгу: правові аспекти захисту дітей від насильства. Науковий вісник Ужсгородського національного університету. Серія : Право. 2020. Вип. 60. С. 127-130.

8. Радченко О. В., Погорелий С. С. Моделювання інформаційної взаємодії між органами публічної влади та суспільством. Публічне управління : теорія та практика : зб. наук. пр. 2012. № 3(11). С. 77-85.

9. Рекомендація CM/Rec (2018)7 Комітету міністрів державам-членам про принципи дотримання, захисту та реалізації прав дитини в цифровому середовищі (Ухвалено Комітетом Міністрів 4 липня 2018 року на 1321-му засіданні заступників міністрів). Страсбург. 2018. Офіційний веб-сайт Національної Ради України з питань телебачення і радіомовлення. URL : https://www.nrada.gov.ua/rada-yevropy-zatverdyla-shhe-odyn-vazhlyvyj-dokument-shhodo-zahystu-prav-ditej/

10. Серьогіна Т. В. Система захисту прав дітей як об'єкт державної політики. Аспекти публічного управління. 2018. Т. 6, № 11-12. С. 64-71.

11. Тильчик О. В., Мердова О. М. Розбудова діяльності державних органів щодо забезпечення та захисту прав дітей: організаційно-правовий аспект. Вісник Львівського торговельно-економічного університету. Юридичні науки. 2018. Вип. 7. С. 112-119.

12. Трестер Ю. Безпека дитини як основа формування і розвитку людського капіталу. Evropsky politicky a pravni diskurz. 2015. Vol. 2, Iss. 3. C. 161-167.

\section{References:}

1. Antonova O. (2017). Mizhnarodno-pravovi standarty u sferi sim"yi, dytynstva, materynstva i bat'kivstva [International legal standards in the field of family, childhood, motherhood and fatherhood]. Al'manakh mizhnarodnoho prava - Almanac of International Law. Vol. 18. 103-112. [in Ukrainian] 
2. Drozd O., Khutoryanska T. (2015). Mizhnarodni standarty zabezpechennya prav i zakonnykh interesiv dytyny ta yikh implementatsiya $\mathrm{v}$ zakonodavstvo Ukrayiny [International standards for ensuring the rights and legitimate interests of the child and their implementation in the legislation of Ukraine]. Aktual'ni problemy derzhavy i prava - Current issues of state and law. Vol. 75. 255-261. [in Ukrainian]

3. Korystin O. Y., Veselov M. Y. (2019). Teoretyko-metodolohichni zasady shchodo kontseptualizatsiyi instytutu zabezpechennya prav ditey [Theoretical and methodological principles for conceptualizing the institution of ensuring children's rights]. Nauka i pravookhorona - Science and law enforcement. Vol. 1.91-99. [in Ukrainian]

4. Krestovska N. (2018). Lyuds'ka hidnist' dytyny: moral'ni ta pravovi aspekty [Human dignity of the child: moral and legal aspects]. Evropsky politicky a pravni diskurz. Vol. 5, Iss. 5. 3541. [in Ukrainian]

5. Kudryavtseva O. (2016). Konstytutsiyni ta instytutsiyni zasady zakhystu prav dytyny v Ukrayini ta Pol'shchi: porivnyal'no-pravovyy analiz [Constitutional and institutional principles of protection of children's rights in Ukraine and Poland: comparative legal analysis]. Istoryko-pravovyy chasopys - Historical and legal journal. Vol. 2. 58-62. [in Ukrainian]

6. Olyfirenko Y. (2014). Shlyakhy vdoskonalennya derzhavnoho upravlinnya u sferi zakhystu prav dytyny [Ways to improve public administration in the field of protection of children's rights]. Visnyk Chernihivs'koho derzhavnoho tekhnolohichnoho universytetu. Seriya : Ekonomichni nauky - Bulletin of Chernihiv State Technological University. Series: Economic Sciences. Vol. 2. 264-275. [in Ukrainian]

7. Prots O. E., Romankiv R. V. (2020). Protydiya bulinhu: pravovi aspekty zakhystu ditey vid nasyl'stva [Combating bullying: legal aspects of protecting children from violence]. Naukovyy visnyk Uzhhorods'koho natsional'noho universytetu. Seriya : Pravo - Scientific Bulletin of Uzhhorod National University. Series: Right. Vol. 60. 127-130. [in Ukrainian]

8. Radchenko O.V., Pogoreliy S. S. (2012). "Modelyuvannya informatsiynoyi vzayemodiyi mizh orhanamy publichnoyi vlady ta suspil'stvom". [Modeling of information interaction between public authorities and societ]y. Publichne upravlinnya : teoriya ta praktyka. Vol. 3 (11). 77-85. [in Ukrainian]

9. Council of Europe gives recommendations to member States on children's rights in the digital environment (2018). Recommendation $\mathrm{CM} / \operatorname{Rec}(2018) 7$ of the Committee of Ministers to member States on Guidelines to respect, protect and fulfil the rights of the child in the digital environment. URL : https://www.nrada.gov.ua/rada-yevropy-zatverdyla-shhe-odyn-vazhlyvyjdokument-shhodo-zahystu-prav-ditej/ [in Ukrainian]

10. Seryogina T. V. (2018). Systema zakhystu prav ditey yak ob"yekt derzhavnoyi polityky [The system of protection of children's rights as an object of state policy]. Aspekty publichnoho upravlinnya-Aspects of public administration. T. 6, Vol. 11-12. 64-71. [in Ukrainian]

11. Tylchyk O. V., Merdova O. M. (2018). Rozbudova diyal'nosti derzhavnykh orhaniv shchodo zabezpechennya ta zakhystu prav ditey: orhanizatsiyno-pravovyy aspekt [Development of activities of state bodies to ensure and protect the rights of children: organizational and legal aspect]. Visnyk L'vivs'koho torhovel'no-ekonomichnoho universytetu. Yurydychni nauky - Bulletin of Lviv University of Trade and Economics. Legal sciences. Vol. 7. 112-119. [in Ukrainian]

12. Trester Y. (2015). Bezpeka dytyny yak osnova formuvannya i rozvytku lyuds'koho kapitalu [Child safety as a basis for the formation and development of human capital]. Evropsky politicky a pravni diskurz. Vol. 2, Iss. 3. 161-167. [in Ukrainian] 